\title{
Social Studies Curriculum: An Educational Response Tool to the Different Problems Faced in Family Life Today in Africa
}

\author{
Osuji, Gregory Ekene (Rev. Br. - Ph.D.) ${ }^{1} \quad$ Everlyn Oluoch- Suleh (Ph.D.) $)^{2^{*}}$ \\ 1.Godfrey Okoye University Ugwuomu-Nike, P.M.B. 01014, Thinkers' Corner, Enugu, Nigeria \\ 2.Kabarak University, P.O. Private Bag- 20157 Kabarak, Kenya
}

\begin{abstract}
Family is a gift of God. The holy family of Nazareth (Jesus, Mary and Joseph) exemplifies a model family. A family is the basic social unit of the society based on marriage. It comprises the child (children), their mother and their father. In some extreme cases when children do not arrive, it does not make it less a family. The scripture exposes us to the different realities of family life. It tells stories about births, love and family crises. This is drawn from the first book of the Bible which recorded the stories of Adam and Eve's family with all its burden of violence and enduring strength. There are myriads of problems faced in family life today in Africa. Some of these problems include domestic violence, marital rape, incest, infidelity, hatred, marital slavery, patriarchy, child labour, male child vis à vis female child syndrome, information and communications technologies, just to mention a few. Despite faith response to these problems; a response based on the sacred scripture and the teachings of the church, there is need for its educational response; the Social Studies Curriculum, in order to bring plausible solutions to these problems. This qualitative study, based on content analysis is anchored on the functionalist theory and supported by the conflict theory.
\end{abstract}

Keywords: Marriage, family life, challenges, faith response, educational response, social studies curriculum, Kenya, Nigeria, Africa

DOI: $10.7176 / \mathrm{JEP} / 12-8-08$

Publication date:March $31^{\text {st }} 2021$

\section{Introduction}

"I Greg, take you Eve as my lawful wedded wife. I will love and cherish you for in richer and in poorer, for better and for worse... until death do us part." These are some of the beautiful words couples use in the exchange of their marital vows. So romantic! Is it not? After professing these beautiful words, why do they turn and call each other names such as 'devil,' 'witch,' 'beast,' 'ashawo,' 'covid,' just to mention a few?

Marriage is part of the dynamic life of being a Christian. It is a sanctified state of life. It renders the wife and husband holy through all those acts that constitute the marriage. This graced dynamic begins with the exchange of marriage vows and through the consummation of the marriage in sexual intercourse. The process of sanctification continues through their life together. God proclaimed marriage very good, entailing good news for humanity as well.

Drawing from the scriptures, God created and blessed marriage in the beginning as Trinitarian image. God said:

Let us make man in our image, to our likeness... So, God created man in the image of himself, in the image of God he created him, male and female he created them. God blessed them, saying to them, be fruitful, multiply, fill the earth and subdue it. Be masters of the fish of the sea, the birds of heaven and all the living creatures that move on earth. (Gen. 1: 26-28 - Jerusalem Bible)

Despite God blessing marriage in the beginning, the Old Testament still reports tragic stories about families. Adam and Eve for example were disobedient to God, but Adam blamed Eve for their failure. They parented Cain and Abel, and Cain killed his brother Abel because of greed and jealousy. Abraham, the man of faith and God's chosen married two wives and broke God's design of one wife and one husband. He even maltreated the younger wife by kicking her out of the house with her child. Jacob married many wives so as David. Sadly, David's son raped his sister. Deducing from these tragic stories about family, it is obvious that there are different problems faced in family life. Today's families are not spared anyway.

Marriage is a created reality and a primordial sacrament. This is exemplified in the scriptures. In Jesus Christ's teaching on marriage and divorce in the New Testament, Matthew records as follows:

Have you not read that from the beginning, the Creator made them male and female and said, for this reason, a man shall leave his father and mother and be joined to his wife, and the two shall become one flesh? So, they are no longer two, but one flesh. Therefore, what God has joined together, no human being must separate. (Mathew 19: 4-6)

Marriage is a divinely instituted sacrament. From the beginning, it is a covenant where man and woman exist mutually for one another in self-giving till death. The joining together of a man and woman to become one gives rise to a family. Therefore, embedded in the goodness of man and woman is their masculinity and feminity which carries with it their task and purpose to form one flesh union and within which communion, procreation, and stewardship are implied (Agugo, 2013). Family is really God's gift. Family is the basic social unit of the society 
based on marriage. It comprises the child or children, their mother and their father. In some cases, children do not arrive. However, it does not make it less a family.

Family life which springs from marriage is very essential in our society today. For the common good of its members and of the society, the family is the place of development, refreshment, maturation and socialization. It is also a place where children learn solidarity and live a life of communion and love. It has been observed that a united family bears witness to the love of God, and it is the image of the Holy Trinity and of the love of God for humanity. The family of Jesus, Mary and Joseph was one that is worthy of emulation. There were joys and struggles all through and they endured them all in faith. They loved one another. Later on, Jesus realised that he couldn't restrict himself solely to his natural family because of his mission. However, he did that in love, but he didn't forget his earthly family also.

It has been observed that marital problems are on the increase. Some studies also have confirmed the increase in marital problems (Omoniyi-Oyafunke, Falola, \& Salau, 2014). There are different problems faced in family life in Africa today. Some of these problems include: Physical assault, rape, verbal abuse, incest, infidelity, hatred, marital slavery, patriarchy, child labour, male child vis à vis female child syndrome, information and communications technologies, just to mention a few. According to Amadi and Amadi (2014), the causes of these problems include the following: Social incompatibility of partners, unrealizable ideals/standards, sexual incompatibility, infidelity/extra marital sexual affairs, infatuations/fantasies, lack of mutual respect, poor moral character, negligence/insensitivity to marital responsibilities, poor marital communication, absence/poor courtship, egocentrism, extreme sexual orientation, third party syndrome, gossip/nagging tendencies, barrenness, and the desire for male children.

For the purpose of this study, these causes are categorised under the following factors: Family socio-economic background, level of education of the spouses, and crude traditions and customs. Studies have shown that many a time, these problems destabilize the family and lead to misunderstanding, separation and divorce. Hence, having adverse effect on every member of the family (Amato, 2000; Kelly, 2006; Mooney, Oliver \& Smith, 2009).

In his post-synodal apostolic exhortation; Amoris Laetitia, Pope Francis (2016) expressed that couples often confront marital problems in haste. That they find it difficult to have patience and reflect on the issue before taking decisions. More so, they are unable to make sacrifices and forgive one another. He continues that this attitude creates family situations that are complex and problematic for Christian life. That is why he concludes with a prayer focusing on the Holy Family of Nazareth. He prayed that God may grant that families be places of communion and prayer, authentic schools of the Gospel and small domestic churches. That families may never again experience violence, rejection and division. That all who have been hurt or scandalised may find ready comfort and healing.

As the head of a religious body, the catholic church, the Holy Father has demonstrated his apostolic role. He used a pastoral approach in responding to the different problems faced in family life today. It seems faith response only is not enough because these problems are still on the increase. Therefore, there is need for its educational response. The social studies curriculum of Kenyan and Nigerian secondary schools can bring plausible solutions to these problems. This is the need for this study.

\section{Theoretical Framework}

This study hinges on the Functionalist Theory, then the Conflict Theory supports it. Emile Durkheim developed the Functionalist Theory in the 1940s. The theory posits that the different parts of society are primarily composed of social institutions with different needs and roles. The institutions such as family, government, media, education, and religious play important role in the society. According to Functionalist Theory, an institution only exists because it serves a vital role in the functioning of society. If it no longer serves a role, an institution will go into extinction. However, when new needs evolve or emerge, new institutions will be created to meet them. The Functionalist Theory or Functionalism opines that society is a system of interconnected parts that work together in harmony to maintain a state of balance and social equilibrium for the whole.

Relating this theory to family life, the family provides a context for reproducing, nurturing, and socializing children. Therefore, when there is a dysfunctional family, it affects every member of the family. This effect also spreads to all the social institutions in the society. The family is an important social institution that play a key role in stabilizing society. It is the primary agent of socialization.

When children are produced in the family for example, it is the responsibility of the family to train them for adult life. It is the duty of the family as the primary agent of socialisation and enculturation to teach these children the values, cultural norms, beliefs, positive attitudes, and different gender roles of the society. In the family also, parents teach their children manners and civility. Therefore, a well-mannered child reflects a well-mannered parent, therefore, a transformed society (Ashley, 2020).

One of the weaknesses of the Functionalist Theory is that it does not encourage the members of the family to take an active role in changing the ills of the family. This is because it sees agitating for social change as undesirable in the sense that the other organs of the social institutions would contribute to the solutions of the 
problems being encountered in one institution. For example, the school could help correct the challenges from the family.

In order to overcome the weaknesses of the Functionalist Theory in understanding the different problems in family life comes the Conflict Theory. Karl Marx was the proponent of the Conflict Theory in about 1848. The Conflict Theory posits that the society is in a state of perpetual conflict because of competition for limited resources. It further holds that social order is maintained by domination and power, rather than by consensus and conformity. It further buttresses that those with wealth and power try to hold on to it by any means possible, chiefly by suppressing the poor and powerless. Therefore, the central tenets of the Conflict Theory are the concepts of social inequality, the division of resources, and the conflicts that exists between different socioeconomic classes (Barnier, 2020).

Relating this to the different problems in family life in Africa, the researchers observe that the more advantaged spouse either by culture, or by level of education, or by socioeconomic status becomes the boss of the home. He or she tries to lord it over the other. This inadvertently creates problems in the family; many a time, leading to misunderstanding, separation or divorce.

\section{Conceptual Framework}

The schematic representation of this study is informed by the literature reviewed and the theories that the study anchored on. This conceptual framework looks at the interrelationship between the independent and dependent variables. That is, problems in family life today, and their educational response. It also looks at some extraneous variables that could have influence on the dependent and independent variables.

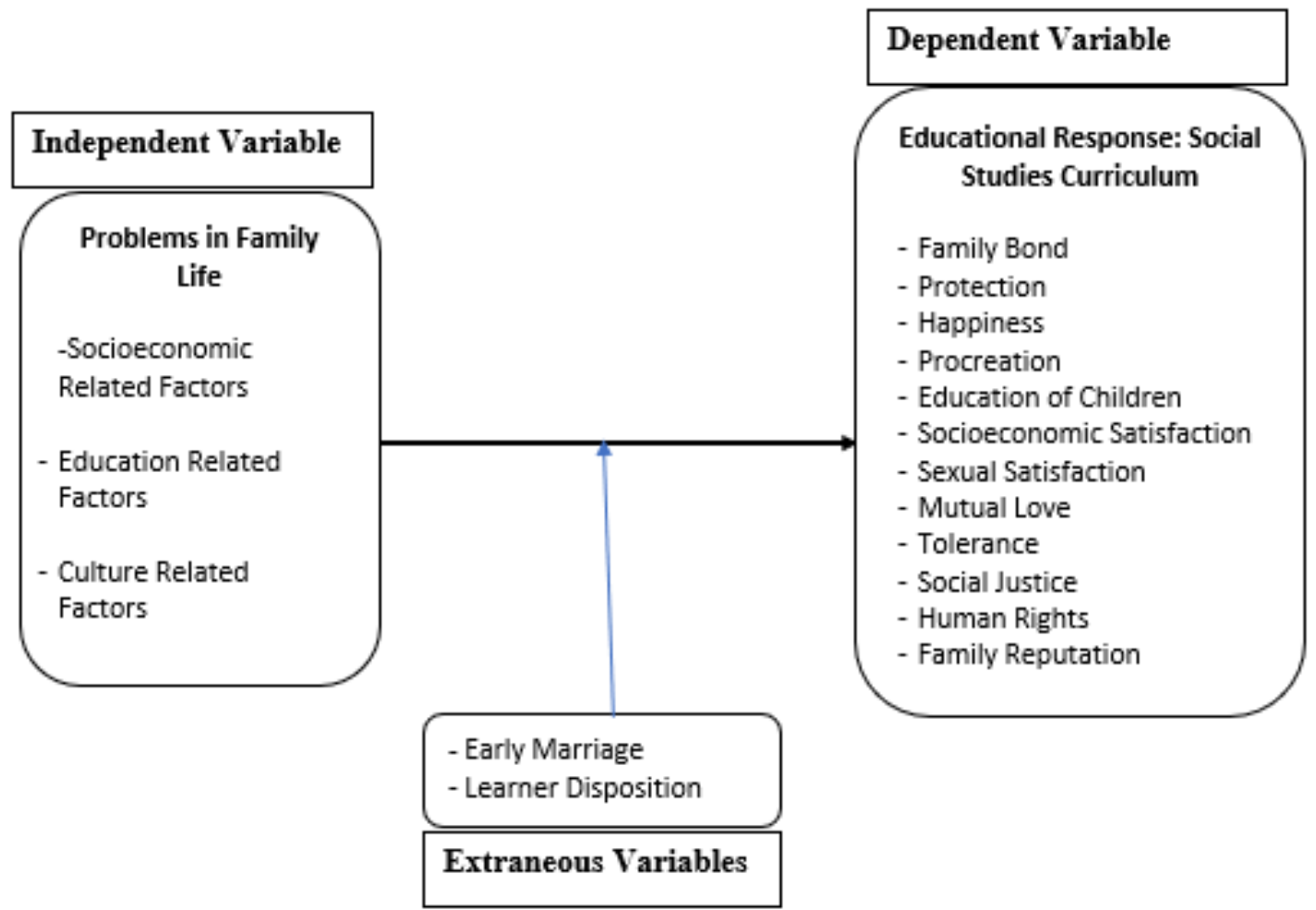

Figure 1: Schematic Representation of the Interrelationship of the Variables of the Study

\section{Challenges faced in Families: A Case of a Nigerian Family}

Adanne got married in January 2005 at the age of twenty years old and in February 2020, at the age of thirty-five years old, the husband sent her out of the house. It is unfortunate that this happened to a naïve lady who had only secondary education at the instance of her marriage. The worse still, the estranged husband denied her access to her four beautiful and handsome children. What a pity! This is one of the disadvantages of early marriage and lack of adequate level of formal education and empowerment before marriage.

In sharing her personal experience, she expressed that for the fifteen years she was in the marriage, she was really a slave; that is, modern slavery under the guise of marriage. God instituted marriage and the family when he created the first man and woman (Gen. 1:2-27; 2:21-24). He blessed marriage and the family and endowed them with their necessary function for the common good of its members and society as a whole. Therefore, both marriage and family have an essential role in God's plan for humanity's salvation.

God ordained that husband and wife should live in harmony and be fruitful, but not one partner living as a 
slave in his or her home. In narrating her ordeal in her marital home, Adanne exclaimed that she lived in 'hell' for those years. Socioeconomically, Adanne came from a poor home while the estranged husband was fortunate to come from a wealthy home. Educationally, Adanne had only senior secondary school certificate while the estranged husband had university degree at the instance of their marriage. Culturally, Adanne married in a home of male dominance where women are not regarded or respected especially if you come from a poor family. All these factors shaped Adanne's marital life.

Marriage and family life are to be enjoyed and endured, but Adanne's was only to be endured. Cultural influences played a major role in her determination to endure until the day she was asked to leave the home. Her society often says; 'the pride of a woman is the husband!' It is quite unfortunate that people still find it difficult to read the writings on the wall and think outside the box. Adanne found herself locked up in this cultural influence because of her beloved children and poor family background.

Adanne was the home manager, but she was never appreciated or respected by the estranged husband. In her marital home, the estranged husband forbade her of addressing him by his name, rather, 'sir' at every instance. However, the husband was fond of addressing her by her first name with no iota of respect even in public. Adanne was physically abused almost on daily basis, intentionally starved economically, and sexually molested against her own volition. These are some of her woes as a married woman. Adanne was not permitted to open and operate a personal bank account, and she was not allowed to receive any gift from anybody apart from the estranged husband.

The estranged husband was often and openly having sexual affairs with different women at different times. Adanne could not do anything because of her poor academic background, poor socioeconomic background and rigid cultural background. All these shaped her life and made her lived in bondage in a home that she was supposed to enjoy and have full rights as a married woman and mother of four children. Finally, Adanne was sent packing after receiving horrible beatings of her life with tent pole and belt simply because she made a video call to her marriage counsellor. Here, everybody blames her for the call, that she would have avoided the estranged husband. Within six weeks that he sent Adanne packing, he brought in another woman in the house who was a month pregnant. What a world! This is where one of the weaknesses of the Functionalist Theory manifested. Adanne was not encouraged to take an active role in changing the ills of the family. This is because her culture sees agitating for social change as undesirable since she is a mother; that she needed to remain a slave in her home because of her children.

The estranged husband, even not being remorseful of his wicked and oppressive acts, fumes and writes in a Facebook public wall: 'After transforming the lifestyle of your poverty-stricken family, you repaid me by bringing shame to my family. You will die a shameful death and I will be alive to bury you. You prostitute and public towel, I curse you this day.' Wow! This is the lady he exchanged marital vows with and promised to be with her for better and for worse until death. Simply put, ingratitude is a vice before God and humanity and should be condemned in its entirety. However, how you treat those you help matters. It is much better sometimes not to help instead of obliterating a person's self-esteem in the process. In helping someone, you have always to bear in mind that they may get to the point where they can survive without you.

Around the time of the Second Vatican Council, a new set of criteria for dissolving marriages was established by the marriage court of the Vatican, which is called the Rota. It allowed the church to declare that a given marriage lacked certain essential qualities that the church held as necessary for the existence of a Christian marriage. If the marriage lacked certain essential qualities, then the parties were given an annulment, which indicates that a Christian marriage was not canonically valid. Essential qualities may be absent in the intention of one or both parties at the time of the wedding, for example, an unwillingness to have children. Or one or both parties may have a personal psychological predisposition that makes them incapable of establishing a lifelong union of life and love. In this scenario, does Adanne's estranged husband have a personal psychological disposition for marriage? What could be the fate of their children who are now under his custody? What type of formation would they receive from him since he denied their mother access to them even phone calls? Of what impact would this separation have on the children's academic wellbeing? These are some questions accruing from this experience.

\section{Impact of Family Breakdown on Children's Academic Wellbeing}

Crisis in family life always have adverse effect on the members of that family. When there is domestic violence, separation or divorce in the home, children of that home for example suffer a lot especially with regard to their academic life. The academic wellbeing of the children is mostly affected and this arguably may make them not to be productive in the society.

Amadi and Amadi (2014) did a quantitative study on marital crisis in the Nigerian society. The study focused on its causes, consequences and management strategies. The findings of the study indicate that marital crisis accrue as a result of many factors including social and sexual life, lack of marital confidence and economic disquiets. This marital crisis has adverse effect on the academic achievement of the children. The study therefore concludes that integrating pre-marriage courses and family living into the curriculum of the Basic Education Programme 
would go a long way in curbing this mayhem. This is the essence of the present study, the need for social studies curriculum to bring plausible solutions to the different problems of family life in Africa today.

Also, Akanbi (2014) did a quantitative study on the impact of divorce on the academic performance of senior secondary students in Ilorin metropolis of Kwara State, Nigeria. The study concludes that students from divorced families show decreased functioning in academic performance and display oppositional behaviour, or signs of anxiety and depression. Further, that the students lack the ability to concentrate in class. There is also decline in class attendance and willingness to participate actively in class because of difficulty in adjusting to a transition in family dynamics.

In his master's dissertation, Yakubu (2017), studied the influence of broken home on academic performance among primary school pupils in Paikoro, Niger State, Nigeria. The study focused mainly on pupils who their parents were either separated or divorced. The study found that parental separation and divorce have no significant differential influence on the academic performance pupils. However, that parental care has a significant differential influence on the academic performance of pupils. It reiterated that pupils with mother care performed better academically than pupils with father care in the achievement test administered. The study concludes that pupils from single-parenting homes exhibit lower academic achievement than those from intact homes where both parents are present.

Pannilage (2017) in his qualitative research worked on the impact of family on the wellbeing of children. The study was done in the Hambantota, Batticaloa and Vavuniya districts of Sri Lanka. The study found that there were a large number of inter-related causes that negatively effects on children's wellbeing. These reasons included the family disharmony, lack of love, care and affection to the children, children exposure to the family violence, family income and discrimination of families due to socio-cultural reasons. This study focused on the general wellbeing of children. It was however disclosed that crisis in the family have negative impact on the general wellbeing of children. Therefore, their academic wellbeing is also affected as a result of the marital problems at home.

In another study done in Denmark, Laursen, Madsen, Obel, and Hohwu (2019) worked on family dissolution and children's social well-being at school. Their study operationally defined social wellbeing as children's perception of sense of belonging in the school setting, in the class and the school community, as well as perceptions on safety, loneliness and bullying. The findings of the study disclosed that a total of $5 \%$ of the children had a low social well-being at school. Among the $31 \%$ who lived in dissolved families, the study found more children with a low level of social well-being at school than those in intact families. The study concludes that children from dissolved families had higher odds for low social well-being at school compared with children from intact families, especially those who experienced family dissolution in the preschool age.

Drawing from the studies reviewed, it is crystal clear that problems faced in families affect the academic wellbeing of the children of those homes. Children from broken homes find it difficult to adjust in school. They are psychologically affected by the trauma of the violence at home. This makes them to lack concentration in academic activities. Therefore, the present study sees the need to respond to these problems using the social studies curriculum.

\section{Educational Response to Problems in the Family: The Role of Social Studies Curriculum}

The different problems in family life in Africa today need an urgent educational response in order to curb the mayhem. There is need for the Social Studies Curriculum to address these problems: socioeconomic related, education related, and culture related family problems. Drawing from the findings of Amadi and Amadi (2014), integrating pre-marriage courses and family living into the curriculum of the Basic Education Programme would go a long way in addressing the issues of family problems in Africa.

Social Studies is the study of people in relation to each other and to their environment. Specifically, Social Studies is issues focused and inquiry based interdisciplinary subject that draws upon history, geography, ecology, economics, law, philosophy, political science and other social science disciplines. The cordial relationship in families is one of the issues that Social Studies as a subject or discipline focuses on.

For the purpose of this study, the Social Studies curriculum prepared in Nigeria by Education Resource Centre (2014) was used to analyse the different problems faced in family life in Africa today and their educational response. This curriculum envisaged challenges in family life and brought in some topics that could remedy the situation. The learner's disposition to adhere to the contents of this curriculum is presumably one of the extraneous variables for the incessant family problems that are being experienced in family life today.

In the first term of Junior Secondary School One (JSS 1), the Social Studies Curriculum as expressed in schemes focus on the family as a primary social group. This topic covered the whole of weeks two to eight. The topic enables learners to dispose themselves to belong to this basic social unit called the family. Here, it helps the learners to understand that each family is unique and has a special value.

In JSS 2, the topics that relate to family are in the first term also. Weeks two to four look at 'family bond and living together as one family.' In this topic, the learners are required to learn the advantages of living together as one family. Some of these advantages are: protection, happiness, unity, education of children, maintaining good 
family name and reputation. Weeks five to seven focus on the 'purpose of marriage.' Some of the purposes as contained in the curriculum are: procreation, satisfaction (economic and social needs), sexual satisfaction, and growth in mutual love.

Then, weeks eight to ten look at 'readiness in marriage.' Some of the sub-topics in this topic are: physiological fitness, psychological fitness, social stability, and financial readiness. Week ten on its part concentrates more on the 'effects of lack of readiness on marriage relationship.' Some of the effects as stipulated in the curriculum are: constant fight, instability, divorce and broken home.

The JSS 3 Social Studies Curriculum focuses on 'promoting peaceful living in the society.' This topic is treated in the second term of JSS 3. The topic establishes some of the ways of promoting peace. Some of these ways are: tolerance, social justice and promotion of human rights.

Analysing the contents of this curriculum, it is observed that the curriculum is rich enough in promoting peaceful living in families. The curriculum has all it takes to curb marital crisis. Despite the values inherent in this curriculum, why is there still increase in marital crisis? This is where the learner's disposition to learn and put into practice what he or she has learnt come to play. Therefore, there shouldn't have been marital crisis in homes if learners are properly guided using the Social Studies Curriculum. The topic in weeks eight to ten; 'readiness in marriage,' needs to be a benchmark for any marital union of a man and a woman.

\section{Conclusions and Recommendations}

It is a known fact that family life springs from marriage, and marriage is a sacred institution ordained by God. Family life is very essential in the society today. For the common good of its members and of the society, the family is the place of development, refreshment, maturation and socialization. It is also a place where children learn solidarity and live a life of communion and love. It is an open secret that a united family bears witness to the love of God, and it is the image of the Holy Trinity and of the love of God for humanity. The family of Jesus, Mary and Joseph; the Holy Family of Nazareth is the model of every family.

It has however been observed that there are different problems families in Africa are faced with. Some of these problems are socioeconomic related, education related, and culture related. Some studies have also shown that these problems in the families affect every member of the family. Specifically, domestic violence, separation, and divorce affect the academic wellbeing of children in these homes.

Drawing from the findings of the study, the researchers recommend the following:

1. Domestic violence, separation, and divorce is on the increase in families in Africa. Therefore, couples should be psychologically ready before tying the nuptial knots together.

2. Oppression and wickedness dominate some families in Africa. Therefore, every spouse is encouraged to be empowered financially in order to be self-sustained so as to avoid any form of economic oppression and wickedness.

3. Early marriage and low level of education are observed as some of the reasons for marital crisis in families in Africa. Based on this, parents are encouraged to train their children educationally to a certain level before allowing them to venture into marriage. More so, their children should attain certain age and maturity before marriage.

4. Culture is perceived as an obstacle to women emancipation in Africa. Therefore, cultural stakeholders in Africa should review some traditions and customs that give men edge over women. The Government should also avail favourable framework that respects the dignity and rights of every individual in the society.

5. The Social Studies Curriculum has the ability to curb the mayhem of marital crisis. Therefore, the Ministries of Education should make it compulsory at all levels of education.

6. Since marital crisis affects the academic wellbeing of children, spouses are encouraged always to accommodate the weaknesses of each other so that their actions at home would not have negative effect on their children's wellbeing.

\section{References}

Agugo, J. K. (2013). Marital intimacy and communion: A mutual vocation to holiness. Lagos: FourthMan Creations.

Akanbi, M. I. (2014). Impact of divorce on academic performance of senior secondary students in Ilorin Metropolis, Kwara State. Research on Humanities and Social Sciences, 4 (19), 103-107.

Amadi, U. P. N. \& Amadi, F. N. C. (2014). Marital crisis in the Nigerian society: Causes, consequences and management strategies. Mediterranean Journal of Social Sciences, 5 (26), 133-143.

Amato, P. R. (2000). The consequences of divorce for adults and children. Journal of Marriage and the Family, $62,1269-1287$.

Ashley, C. (2020). Understanding functionalist theory. Retrieved from thoughtco.com/functionalist-perspective3026625 . 
Barnier, B. (2020). The conflict theory. Retrieved from https://www.investopedia.com/terms/c/conflict-theory.asp Education Resource Centre. (2014). FCT junior secondary school teaching schemes. Abuja: ERC Mini Press.

Kelly, J. B. (2006). Children living arrangements following separation and divorce: Insights from empirical and clinical research. Family Process, 46, 35-42.

Laursen, L. L., Madsen, K. B., Obel, C., \& Hohwu, L. (2019). Family dissolution and children's social well-being at school: A historic cohort study. BMC Paediatrics, 19, 449.

Mooney, A., Oliver, C. \& Smith, M. (2009). Impact of family breakdown on children's wellbeing. London: Institute of Education, University of London.

Omoniyi-Oyafunke, C., Falola, H. O., \& Salau, O. P. (2014). Effect of marital instability on children in Abeokuta metropolis. European Journal of Business and Innovation Research, 2 (3), 68-77.

Pannilage, U. (2017). Impact of family on children's wellbeing. Journal of Sociology and Social Work, 5(1), 149158.

Pope Francis. (2016). Amoris laetitia. Rome: Vatican Press.

Yakubu, A. P. (2017). Influence of broken home on academic performance among primary school pupils in Paikoro, Niger State, Nigeria, (Unpublished master's dissertation). Ahmadu Bello University, Zaria. 